\title{
Gyermekireziliencia- és szülőikompetencia-mérések a magyar gyermekvédelemben
}

\section{Measurements of child resilience and parental competences in the Hungarian child protection}

\author{
HOMOKI ANDREA \& RÁCZ ANDREA ${ }^{1}$
}

\begin{abstract}
Homoki Andrea: Gál Ferenc Egyetem, Egészség- és Szociális Tudományi Kar, Egészség- és Szociális Tudományi Intézet, Szociális Munka Tanszék (Gyula); homoki.andrea@gff-gyula.hu

Andrea Homoki: Gál Ferenc University, Faculty of Health and Social Sciences, Institute of Health and Social Sciences, Department of Social Work (Gyula, Hungary); homoki.andrea@gffgyula.hu
\end{abstract}

Rácz Andrea: Eötvös Loránd Tudományegyetem, Társadalomtudományi Kar, Szociális Tanulmányok Intézete, Szociális Munka Tanszék (Budapest); racz.andrea.aniko@ tatk.elte.hu

Andrea Rácz: Eötvös Loránd University, Faculty of Social Sciences, Institute of Social Studies, Department of Social Work (Budapest, Hungary); racz.andrea.aniko@tatk.elte.hu

\begin{abstract}
Absztrakt
Hazánkban immár három körben valósult meg (2018-2020) és jelenleg is zajlik (2020-2021) egy olyan modellprogram, mely azt hivatott elősegíteni, hogy a család- és gyermekjóléti szolgáltatásban, gyermekvédelmi szakellátásban dolgozó szakemberek számára olyan kipróbált és hatékony eszközök álljanak rendelkezésre, melyekkel eredményesebben tudják végezni a gondozási tevékenységüket, kezelni a családon belüli problémákat, hatékonyabban tudják motiválni a családot a pozitív irányú változásokra.

Tanulmányunkban bemutatjuk a gyermekireziliencia- és a szülőikompetencia-méréseket, és azt, hogy ezek hogyan tudnak egy-egy program értékelésén túl a gyermekvédelmi munkában széles körben hasznosulni.
\end{abstract}

Kulcsszavak: gyermekireziliencia-mérések, szülöikompetencia-mérések, gyermekjóléti komplex problémák és szolgáltatói válaszok

\begin{abstract}
A model program has been implemented in three rounds (2018-2020) and it is currently taking place (2020-2021) in Hungary. The aim of this program is to give effective tools for professionals in the field of child welfare services and in the child protection system to carry out the care activities, deal with family problems, motivate the family for positive change in much more effective way. In this study, the measurements of child resilience and parental competences are
\end{abstract}

\footnotetext{
${ }^{1}$ A program a Rubeus Egyesület keretében valósul meg. Rácz Andrea részt vesz a projekthez tematikusan kapcsolódó Szolidaritás a késő modernitásban c. OTKA-kutatásban (FK 129138, 2018-2020, Sik Domonkos), a Menekülés az államtól: privatizáció, exit-stratégiák és alternatív szolgáltatások a gyereknevelésben c. OTKAkutatásban (FK 135215, 2020-2023, Berényi Eszter), valamint a COST Action 19106-Multi-Sectoral Responses to Child Abuse and Neglect in Europe: Incidence and Trends c. projektben az ELTE TáTK Szociális Munka Tanszék képviseletében.
} 
Homoki A. \& Rácz A.: Gyermekireziliencia-és szülöikompetencia-mérések...

presented. The goal is to highlight how these measurements can - beyond to evaluate concrete programs - be widely used in the child protection practice.

Keywords: child resilience measurements, parental competence measurements, complex problems and responses in the child welfare system

\section{A reziliencia jelentősége a gyermekvédelemben}

A reziliencia különböző fogalmi meghatározásainak közös kiindulópontja a „rugalmasság”, amely társadalomtudományi paradigmaként egy olyan sajátosságként értelmezhető, ami az egyént a hosszan tartó nehézségek, súlyos traumatizáló hatások ellenére is képessé teszi a boldogulásra. A reziliencia azokat a személyes és környezeti tényezőket foglalja magába, amelyek elősegítik a veszélyeztetett életkörülmények ellenére történő sikeres alkalmazkodást, csökkentik a stressz negatív hatásait, és lehetővé teszik az egyén számára, hogy a változásokkal képes legyen megbirkózni (Kiss és mtsai., 2015: 94). Kutatók felhívják a figyelmet arra, hogy minél több hátránnyal szembesül és képes az életében megbirkózni a reziliens személy, annál nagyobb sikert ér el (Csepeli és mtsai., 2004, idézi: Homoki, 2020: 212).

A rezilienciát különféle metaforákkal írták le, Masten (2001) „hétköznapi csodának” hívja, mely azt is jelenti, hogy egy fejleszthető képességként értelmezhetjük. A gyermekvédelem különböző színtereit a jelenség vizsgálatára kiválóan alkalmasnak tartjuk, hiszen minden érintett gyermek életében fellelhetők azok az életesemények, melyek a problémákkal való megküzdést, az azokon való átlépést, a lefelé húzó „mocsárból” (Sahoo, 2011) való felrugaszkodás képességét feltételezik (Homoki, 2016).

A pozitív és negatív irányú folyamatokra ható faktorok müködésének megértését segítheti két modelltípus: az ún. kiegyenlítő és az ún. védőfaktor modell. Míg az előbbi szerint a rizikófaktorok semlegesítésével, ellensúlyozásával tud az egyén közvetlen, pozitív hatást elérni, azaz a kiegyenlítő modell előnyökről, erőforrásokról, protektív faktorokról beszél, és figyelmen kívül hagyja a károsító hatás erősségét, addig a második, a védőfaktor modell akkor bír nagyobb erővel, amikor a károsító ágens erősnek mutatkozik. Ez a modell alacsony mértékü kihívás esetén nem érvényes (Urbán \& Kovács, 2016: 48). A reziliencia fontossága, ereje abban rejlik, hogy egy optimális reziliens megküzdési stratégia a legtöbbet hozza ki az adott helyzetből, éppen ezért a 21. század nemzetközi és hazai rezilienciakutatásainak (Connor \& Davidson, 2003; Járai és mtsai, 2010; Liebenberg és mtsai, 2012; Hámori, 2013; F. Lassú és mtsai, 2015; Homoki, 2014, 2016; Knapek és mtsai, 2015; Masten, 2012) egyik kiemelkedő kérdése - a korábban már feltárt gátló- és védő tényezőcsoportok, faktorok ismeretében -, hogy miként segíthető elő leginkább a reziliens válaszokon alapuló müködés. Különböző korcsoportokban, klienskörökben, társadalmi csoportokban, helyi közösségekben hogyan fejleszthető az a képességrendszer, mellyel egy-egy nehézséget, traumát, betegséget, veszteséget megélve, minél rövidebb idő alatt képessé válhatnak az egyének, családok, intézmények élhető életmódjuk folytatására, maradandó társadalmi funkciókiesés, -csökkenés nélkül?

\section{Gyermekireziliencia- és szülöikompetencia-mérések}

Hazánkban három körben valósult meg (2018-2020) és jelenleg is zajlik (2020-2021)² egy olyan modellprogram, mely azt hivatott elősegíteni, hogy a család- és gyermekjóléti

\footnotetext{
${ }^{2}$ 1. program: http://rubeus.hu/projektek/szuloi-kompetenciak-fejlesztese-erositese\#more-607
} 
szolgáltatásban, gyermekvédelmi szakellátásban, illetve komplex gyermekvédelmi programban érintett szociális szakemberek számára olyan kipróbált és hatékony eszközök álljanak rendelkezésre, melyekkel eredményesebben tudják végezni a gondozási tevékenységüket, kezelni a családon belüli problémákat, hatékonyabban tudják motiválni a családot a szükséges változásokra. Minden alkalommal a szülőség megerösítése, a szülő-gyermek kapcsolat támogatása a cél különböző szolgáltatók, illetve civil partnerek bevonásával. Minden fejlesztési körben néhány partnerszervezet dolgoz ki saját fejlesztésű módszereket, melyek jól illeszkednek saját gyakorlatukhoz, ugyanakkor innovációnak számítanak a gyermekjóléti, gyermekvédelmi területen. Mivel a projekt támogatója a Belügyminisztérium és a Nemzeti Bűnmegelőzési Tanács, így a bűnelkövetés megelőzése is kiemelt jelentőségű a programokban. A modellhelyszínek arra kapnak lehetőséget, hogy minimum 25 család és 50 gyermek megszólításával dolgozzák ki saját eszköztárukat (programonként minimum 100 család és 200 gyermek bevonása történik meg), ezeket próbálják ki néhány hónapos időtávban, és dokumentálják a szakmai munka előrehaladását, hogy a tapasztalatok széles körben megoszthatók legyenek a szakmában. A célcsoportja tehát a szülők és a gyermekek köre, akik valamilyen gyermekvédelmi problémával küzdenek, akár családban vagy már a szakellátásban él a gyermek, illetve a családokkal dolgozó szakemberek köre, akik a programelemek révén azon dolgoznak, hogy a szülöi kompetencia fejlesztésével erösödjön a szülö-gyermek kapcsolat, a nevelésbe vett gyermekek esetében pedig elősegíthető legyen a mielőbbi hazagondozás.

Nagyon fontos vállalása ezeknek a szakmai innovációknak, hogy a reziliens müködést segítsék elő a gyermekek és a családok esetében. A programok hatékonyságának és a folyamatos kihívásokkal jellemezhető szakmai munka eredményességének objektív mutatója a szülői attitüdökben és gyermeki rezilienciában kimutatható változás. Erre minden modellprogram esetében egy-egy speciális mérőeszközt fejlesztettünk ki, a gyermekek esetében életkornak és nevelkedési helynek megfelelően, valamint a szülőknek is egyet a program fö témájához illeszkedően. Így pl. a bünelkövetésben vagy a válásban érintett, illetve mentális zavarral, szerhasználattal küzdő szülők számára olyan eszközt, mely alkalmas a szülöi kompetenciák mérésére és a változás nyomon követésére. Ez utóbbit azért is fontos megnéznünk, hogy megtudjuk, hogy egy komplex szakmai program néhány hónap alatt is (3, 6, 7, 10 hónapos támogatási intenzitással dolgoztak az egyes támogatási körökben) képes-e változást indukálni pozitív irányba.

Hatékonyságmérésünknél a nemzetközi és hazai rezilienciaelméletekből indultunk ki, hangsúlyozva azokat a külső környezeti erőforrásokat, melyek az egyének énhatékonyságára tartósan kedvezőtlenebb körülmények között is pozitív hatást gyakorolhatnak (Homoki, 2018).

A modellprogramok kutatási lábában alkalmazott mérőeszközök a magyar gyermek- és ifjúsági reziliencia modell (Homoki, 2014; Homoki \& Czinderi, 2015; Homoki és mtsai., 2016) összefüggésrendszerén alapulnak. A gyermeki reziliencia mérésére a gyermekekkel foglalkozó szakemberek számára könnyen alkalmazható, magas ( 0,8 feletti) Cronbach alfa mutatóval jellemezhető rezilienciaskálát, mérőeszközt fejlesztettünk minden támogatási kör elindításakor. ${ }^{3}$ A rezilienciaskálákon túl alkalmaztuk a szülői attitűdöket vizsgáló kutatási

\footnotetext{
2. program: http://rubeus.hu/projektek/szuloi-kompetenciak-fejlesztese-bunelkoveto-gyermekek-csaladjaban

3. program: http://rubeus.hu/projektek/a-szuloseg-tamogatasanak-uj-utjai-a-gyermekvedelemben

4. program céljai, módszerei: http://rubeus.hu/projektek/csaladi-egyensuly-tamogatasa-a-gyermekvedelemben

3 A skálák itemszámától függően az átlagpontszámok alakulásának figyelembevételével állapítható meg a gyermeki rezilienciaszint (pl.: a GYIRM 25 = 25 itemböl álló skála esetében a gyermekek nehéz élethelyzethez való rugalmassági szintje: 1) alacsony: $\leq 69$ pont (5-ös skálán 3 vagy alacsonyabb átlagpontszám), 2) közepes: 70-
} 
eszközt, mely a programokba bevont szülök esetében a gyermekeikhez, a párkapcsolatukhoz való viszonyulásukra és a családi kommunikációra, családi együttes tevékenységeikre jellemző attitüdjeik mérésére alkalmas (Cronbach alfa 0,7 és 0,8 közötti értéket mutató) kutatási eszköz (Homoki, 2018, 2019, 2020).

A gyermekireziliencia- és szülőiattitüd-kutatás kvantitatív eredményei (2018-2020) minden évben és minden modellhelyszínen, legyen az gyermekjóléti szolgálat, gyermekotthon, javítóintézet vagy speciális gyermekvédelmi funkcióval bíró, hátrányos helyzetủ gyermekek ellátását biztosító kollégium, szignifikáns pozitív irányú változást mutattak a támogatási időtől függetlenül. ${ }^{4}$ Azt tapasztaltuk, hogy a családok reszponzív gyermekjóléti célú támogatására fejlesztett modellprogramok (intenzív családgondozás, szülőklub, kamaszklub, közösségi programok, meseterápia stb.) a gyermeki reziliencia családi alrendszeréhez tartozó tényezőinek fejlődését pozitív irányban mozdították elő, függetlenül az életkori, nemi és térbeli elhelyezkedéstől és a családi privációk jellegétől. Az elemzések során a 20 itemből álló Szülőiattitűd-skálából faktoranalízis módszerével jól elkülönülö, új alskálákat azonosíthattunk, mint például a „Családi, párkapcsolati érzelmek kifejezése”, a „Gyermekkel töltött minőségi idő” és a „Családi feszültségkezelési” alskálák. Mindhárom vizsgálati évben a családban az érzelmek megélésének és kifejezésének fontosságát támogató programok sikerességét jelzi a páros T-próbával mért szignifikáns pozitív irányú eltérés. Az adott alskálán a modellprogramok hatására, a programok zárását követően $\mathrm{p}=0,031$ szignifikancia szinten több pontos emelkedést mértünk a programokban részt vevő szülök körében.

Az évről évre kimutatott pozitív eredmények igazolhatják a modellhelyszíneken fejlesztett és alkalmazott programok célzottságának, szükségletorientáltságának sikerességét, ezáltal alkalmasságukat arra, hogy a mindenkori helyi sajátosságok, szükségletek figyelembevétele mellett jól adaptálhatók a gyermekjóléti, gyermekvédelmi rendszer egyes szegmenseiben.

Az egyes támogatási körökben bevont modellhelyszíneken mért gyermekireziliencia- és szülői attitüdök átlagértékeit a programba való bemenet és kimenet mérési eredményei alapján összehasonlítva a legnagyobb pozitív irányú változás ott mutatkozott, ahol egy-egy gyermekes család több támogatásban is részesült egyszerre, még ha a családtagok külön vettek is ezekben részt, ahol több programelem célozta fejlesztésüket, segítette a szülö-gyermek kapcsolatot és erősítette a szülőséget. Mindez a szociális segítői tevékenység, gyermekvédelmi munka multidiszciplináris, multidimenzionális jellegéből is következik. Korábbi kutatásból tudjuk, hogy a gyermeki rezilienciát látens változóként előmozdító tényezőként jelenik meg a szakmaközi együttműködések kiterjedtsége (Homoki, 2014).

A vér szerinti családjaikban és a gyermekvédelmi szakellátásban, illetve javítóintézetben élő gyermekek és fiatalok rezilienciaszintjének emelkedése 2-18\% között alakult a vizsgált években. Célcsoportonként összehasonlítva a szakellátásban és/vagy javítóintézetben élő gyermekek, serdülők (12-18 évesek) reziliencia szintje emelkedett legnagyobb mértékben 2019-ben, 11\%-kal nőtt a programok befejeztével a magas rezilienciaszinttel jellemezhető gyermekek aránya. 2020-ban a kollégiumban és a vér szerinti

92 pont (5-ös skálán 3-4 közötti átlagpontszám) és 3) magas: 93-125 pont (5-ös skálán 4 feletti átlagpontszám) (Rácz \& Homoki, 2019).

${ }^{4}$ A kutatási eredmények, elemzések részletesen itt olvashatók a Rubeus Egyesület 2018-2020. évi kiadványaiban: http://rubeus.hu/wp-content/uploads/2018/10/szuloi_kompetenciafejlesztes_rubeus_20180919.pdf

http://rubeus.hu/wp-content/uploads/2019/09/konyv_szulomkomp_BM2_final_201906.pdf, http://rubeus.hu/wpcontent/uploads/2020/10/Rubeus_CSALADTAMOGATAS_UJ_UTJAI_2020_FINAL_KONYV_20201008.pdf 
családban élő 10-18 éves korcsoporthoz tartozók körében mértünk 18\%-os emelkedést a magas rezilienciájúak körében.

A közösségi, családi élmények, minőségi idő együtt töltését célzó programok szervezése a legtöbb helyszín esetében az online térben is megvalósulhatott 2020-ban a Covid-19 megjelenésekor.

A mérések eredményei alapján elmondható, hogy a karantén időszaka előtt indított programok, és annak időszakában a családokkal megváltozott térben és módszerekkel végzett szakmai munka, a családok felé való intenzív odafordulás megerősítő hatással bírt a bevont családok és gyermekek életében. A szülőiattitüd-skálára adott válaszaik alapján szignifikánsan igazolható a pozitív fejlődés a szülők érzelmeinek tudatos kifejezésében, a gyermekeikkel együtt töltött otthoni, hétköznapi tevékenységek együttes pozitív megélésében, a családi konfliktusmegoldások során jellemzővé vált nyílt kommunikáció terén. Mind a teljes skálán, mind a fent bemutatott alskálákon mért pozitív szignifikáns változás különösen értékes eredmény 2020-ban, tekintettel a világjárvány okozta nehéz körülményekre.

\section{Összegzés}

A gyermekjóléti és gyermekvédelmi területen megvalósuló modellprogramokban felkért partnerek által kidolgozott és megvalósított komplex programok pozitív hatást gyakoroltak a gyermekek és fiatalok hosszan tartó életnehézségekkel szembeni sikeres megküzdését elősegítő rezilienciára. A szülők minden programban megerősödtek szülői szerepeikben és ez a Covid19 időszakban is mérhető volt. Ez leginkább a szakemberek elköteleződésének, magas szintű felkészültségének, kreativitásának, a jól célzott és átgondolt programoknak köszönhető. A szakemberek napi szintű munkavégzésében is fontosak a mérések, hiszen orientálhatják öket abban, hogy a gyermekek fejlesztése, a családok müködésének megerősítése terén honnan hova szeretnének eljutni. Mindezek a családgondozás, gyermekek célzott fejlesztése, valamint a hazagondozás elősegítése terén is kiemelt fontosságúak lehetnek.

A modellprogramok során a mérések eredményei alapján azt tapasztaltuk, hogy a megvalósításban részt vevő szakemberek nagy erőfeszítéseket tettek és sikeresek voltak az alábbiakban:

- a szülő-gyermek kapcsolat erősítésében,

- a szülőknek gyermekeikkel megélt közös pozitív élményt biztosító, minőségi programok szervezésében,

- a szülök szakemberek felé való nyitottságának, bizalmának növelésében,

- az intenzív támogatás nyújtása révén a családi koherenciaérzés növelésében,

- a családi konfliktusok enyhítésében, kezelhetőbbé tételében, esetleg megszünésében,

- a szakmai teammunka és szakmai identitás erősítésében.

\section{Irodalom}

Connor, K. \& Davidson, J. (2003). Development of a new resilience scale: The Connor-Davidson Resilience Scale (CD-RISC). Depress Anxiety, 18(2), 76-82. https://doi.org/10.1002/da.10113

F. Lassú, Zs., Serfőző, M., Sándor, M., Kolosai, N. \& Pálffy, Zs. (2015). Családi struktúra, szülői bánásmód és lélektani rugalmasság összefüggései serdülőkorban. Alkalmazott Pszichológia, 15(1):77-92. 
Homoki A. \& Rácz A.: Gyermekireziliencia- és szülóikompetencia-mérések...

Hámori, E. (2013). Rizikófaktorok, adaptáció és reziliencia a korai fejlődésben: A koraszülöttség a fejlődési pszichopatológia modelljében. Magyar Pszichológiai Szemle, 68(1), 7-22.

Homoki, A., Czinderi, K., Segal, H., Sándor, Z. \& Fodorné Vidó, R. (2016). A CYRM 28 gyermek és ifjúsági reziliencia skála magyar adaptált változatának jellemzői. http://mindenholotthon.hu/cyrm-28-gyermek-ifjusagi-rezilienciakutatas/

Homoki, A. \& Czinderi, K. (2015). A gyermekvédelmi szempontú rezilienciakutatás eredményei Magyarország két régiójának LHH térségeiben. Esély, 26(6), 61-82.

Homoki, A. \& Rácz, A. (2019). Bünelkövetéssel érintett gyermekeket és szüleiket célzó gyermekvédelmi innovációk. Erdélyi Társadalom, 17(2), 9-30.

https://www.doi.org/10.17177/77171.228

Homoki, A. (2014). A gyermekvédelmi gondozottak reziliencia vizsgálata a Dél-alföldi és az Északalföldi régióban. Debreceni Egyetem. http://hdl.handle.net/2437/201731

Homoki, A. (2016). A boldogulás elösegitése nehéz helyzetben lévő serdülök körében: Gyermekvédelemben élni a szeretet erejével. Áldott Remény Könyvkiadó.

Homoki, A. (2018). A szülői kompetenciafejlesztés hatásai a gyermeki reziliencia fejlődésére. In Rácz A. (szerk.), Szülöi kompetenciafejlesztést célzó modellprogramok a gyermekjóléti szolgáltatások tárházában (pp. 309-341). Rubeus Egyesület.

http://rubeus.hu/wpcontent/uploads/2018/10/szuloi_kompetenciafejlesztes_rubeus_20180919. pdf

Homoki, A. (2019). A szülőikompetencia-fejlesztés hatásai a devianciákkal, bűnelkövetéssel érintett családok gyermekeinek reziliencia-fejlödésére. In Rácz A. (szerk.), Bünelkövetéssel érintett gyermekeket és szüleiket támogató modellprogramok a gyermekvédelemben (pp. 263-295). Rubeus Egyesület.

http://rubeus.hu/wp-content/uploads/2019/09/konyv_szulomkomp_BM2_final_201906.pdf

Homoki, A. (2020). Szülőket és gyermekeiket komplex segítségnyújtással támogató modellprogramok hatékonyságmérése a gyermeki reziliencia és a szülői attitűdök vizsgálatával. In Rácz, A. (szerk.), A szülöség támogatásának új útjai a gyermekvédelemben (pp. 212-236). Rubeus Egyesület.

http://rubeus.hu/wp-

content/uploads/2020/10/Rubeus_CSALADTAMOGATAS_UJ_UTJAI_2020_FINAL_KON YV_20201008.pdf

Járai, R. (2015). A Connor-Davidson Reziliencia Kérdőív 10 itemes változatának jellemzői. Alkalmazott Pszichológia, 15(1), 129-136.

Kiss, E. Cs., Vajda, D., Káplár, M., Csókási, K., Hargitai, R. \& Nagy, L. (2015). A 25-Itemes ConnorDavidson Reziliencia Skála (CD-RISC) magyar adaptációja. Mentálhigiéné és Pszichoszomatika, 16(1), 93-113. https://www.doi.org/10.1556/Mental.16.2015.1.4

Knapek, É. (2015). Reziliencia és korai maladaptív sémák kodependens, borderline és egészséges személyek körében. Alkalmazott Pszichológia, 15(1), 111-129.

Liebenberg, L., Ungar, M. \& Vjiver, F. V. (2012). Validation of the Child and Youth Resilience Measure-28 (CYRM-28) among Canadian youth. https://doi.org/10.1177/1049731511428619

Masten, A. S. (2001). Ordinary magic: Resilience processes in development. American Psychologist, 56(3), 227-238.

Masten, A. S. (2012). Resilience in children: Vintage Rutter and beyond. In A. Slater \& P. Quinn (Eds.), Developmental psychology: Revisiting the classic studies (pp. 204-221). Sage.

Sahoo, F. M. (2011). Foster resilience. http://childrearinghelp.wordpress.com/2011/03/23/fosterresilience

Urbán, N. \& Kovács, L. (2016). A pszichológiai reziliencia, mint integrált alkalmazkodó rendszer. Honvédorvos, 6(3-4), 43-50. https://www.doi.org/10.29068/HO.2016.3-4.43-50 